\title{
MEDIATING CIVIL DISPUTES THROUGH LOCAL WISDOM
}

\author{
Denny Suwondo \\ Sultan Agung Islamic University \\ dhewonr@yahoo.com
}

\begin{abstract}
The purpose of the research is intended to bring people to prosperity, happiness and harmony, so that there is mediation with the value of local wisdom must be the basis of resolution in civil disputes. The approach used in this paper is a normative juridical approach. The findings in this study include That the law is for humans, not humans for the law, whose purpose is to bring people to prosperity, happiness, and harmony. So that there is mediation with the value of local wisdom must be the basis of resolution in civil disputes with due regard to Referring to the win-win solution principle, what is meant by the disputing parties feel that no one is defeated, Achieve the inner glory and inner peace of the parties, Reinforcement of family values and sense of belonging to the disputing parties.
\end{abstract}

Keywords: Civil Dispute, Local Wisdom, Mediation

\section{A. INTRODUCTION}

Law is always related to human beings ${ }^{1}$ who exist in a group of community or society. Humans are social creatures that live interacting with one another. This interaction starts from the simplest level to the greater stage which comes from the simplest level so it will end to a greater and more complex stage along with the developments that occur in a society that covers all aspects of life. The application of social interaction in social life does not always go in harmony and harmony. Often what happens is the difference of thoughts, opinions, and desires between people with one another. Such is the case with the Indonesian nation, which is known as a large and sovereign nation, has a monumental work of the nation, and should be the pride of the nation, which is the result of thinking about the principles of national and state life,namely Pancasila. ${ }^{2}$

The existence of law in the midst of the community is expected to bring order, order, justice, and even bring prosperity to the people. Mochtar Kusumaatmadja states that law is one of the social rules (besides moral, religious, moral, courtesy, customs, etc.), which reflects the values that apply in society that good law is the appropriate law with living (living law). ${ }^{3}$.

1 Sudikno Mertokusumo, Mengenal Hukum (suatu Pengantar), Liberty, Yogyakarta, 1988, page. 1

2 Dini Amalia Fitri, Pancasila As A Legal Science Paradigm, International Journal of Law Reconstruction, Volume 3, Issue 1I, September 2019, page.123-133.

3 Mochtar Kusumaatmadja, Mochtar Kusumaatmadja dan Teori Hukum Pembangunan, Epistama Institute dan Huma, Jakarta, 2012, Page.34 
When differences in interests/rights arise because some feel disadvantaged, it is not impossible. Then it will cause disputes or conflicts in the community. One that occurs is the issue of civil disputes. Civil disputes are civil cases where at least two parties, namely the plaintiff and the defendant. If a dispute arises in the community that cannot be resolved by deliberation, then the injured party can file a lawsuit. This party is called the plaintiff. The lawsuit was filed with the court in charge of resolving the dispute. $^{4}$

Furthermore, in court proceedings, the settlement of a case begins by filing a lawsuit with the competent court, if in filing a lawsuit to the District Court and the lawsuit is declared accepted by the District Court, then by the judge examining the civil case, peace or mediation between the parties is always sought before the civil case examination done.

The existence of peace or better known in the practice of law with the term "mediation" as one form of a number of alternative dispute resolution mechanisms, is not something foreign in the life of the Indonesian people, even including the environment of indigenous peoples with various values of local wisdom because it is part of living social norms.

Likewise, the Qur'an also has explained the concept of mediation by using the language of the word peace as stated in QS An-Nisa'/ 4: 28 which advocates peace to be carried out in a dispute, also in QS An-Nisa'4: 114 which explains that by making peace will be rewarded with a great reward by Allah SWT.

In the Supreme Court Regulation Number: 1 of 2016 in Article 1, it is explained that mediation is a way of resolving disputes through mediators.

Who is the mediator in the Republic of Indonesia Supreme Court Regulation No. 1 of 2016 discussing the Mediation Procedure in the Court and the Judge or other appointed parties can act as mediators who will bring together the parties to the dispute in order to find input on the real issue and based on the subject matter and the desire of each party in the framework of peace to form a peace proposal which is then discussed with the parties to achieve a mutually beneficial outcome.

If there is an agreement between the parties, then it will be written in a written form signed by the parties and then made a peace certificate so that the parties understand and keep what has been agreed. Peace is an agreement whereby the parties, by surrendering, promising or holding an item, terminate a case which is dependent on or prevent the emergence of a case, the agreement is invalid but if made in writing. Besides that right now the parties that have civil disputes prefer to settle it themselves through deliberation with the parties concerned without going through or with the help of a third party. This can depend on good faith (goodwil) from both parties and the level of complexity of the dispute itself.

Peace must be carried out by all parties involved in the case and by those who have the power to do so, and established by a peace deed that has legal force and is final in nature. So before a case hearing is carried

4 Sudikno Mertokusumo, Hukum Acara Perdata, Liberty, Yogyakarta, 2002, Page. 84. 
out, a district court judge always seeks the peace of the parties at the hearing. Judges must be able to provide understanding, instill awareness and confidence to the parties to the litigation, that the settlement of cases with peace is a better and wiser way of settlement than resolved by court decisions, both in terms of time, cost and energy used. ${ }^{5}$

As confirmed in Article 1858 the Civil Code is interesting to observe because the Article states, as follows:

"Among the parties concerned, a peace has the power of a judge's decision at the final stage. That peace cannot be disputed on the grounds that there is a mistake about the law or on the grounds that one of the parties is harmed."

Judges play an active role, so that for the purposes of peace, the hearing is then postponed to provide an opportunity for peace. On the following day, when the court succeeded in making peace, it was conveyed to the judge at the trial of the result of his peace which was normally in the form of a letter of agreement under the handwritten on stamped paper. Based on the existence of peace between the two parties, the judge handed down the verdict (acta van vergelijk), which contents punished both parties to fulfill the content of the peace that had been made by them. The power of this peace decision is the same as an ordinary decision. The purpose of the research is intended to bring people to prosperity, happiness and harmony, so that there is mediation with the value of local wisdom must be the basis of resolution in civil disputes

\section{B. RESEARCH METHODS}

The Reasearch Methods used in this paper is a normative juridical approach. A juridical normative approach is a legal research approach that is carried out by examining library materials or secondary data as a basis for research by conducting a search of the regulations and literature relating to the problem under study. ${ }^{6}$ Data analysis used in this study is descriptive-qualitative by analyzing data/information obtained through descriptive research with library research which is then systematically compiled and described qualitatively. ${ }^{7}$ Secondary data is data obtained from ingredients Pustaka through the study of literature, and these data were also obtained from institutions / agencies related to the goals of this research ${ }^{8}$

5 Netty Herawati, Implikasi Mediasi Dalam Perkara Perdata di Pengadilan Negeri Terhadap Asas Peradilan Sederhana, Cepat, dan Biaya Ringan, Journal Perspective, Volume XVI No. 4 of 2011 September Edition. page. 2.

6 Ahmad Rofiq, Hari Sutra Disemadi, and Nyoman Serikat Putra Jaya, Criminal Objectives Integrality in the Indonesian Criminal Justice System, Al-Risalah 19, no. 2 (December 16, 2019), Page.179-190.

7 Andi Aina Ilmih, Kami Hartono, Ida Musofiana, Legal Aspects Of The Use Of Digital Technology Through Sharia Online Transactions In Traditional Markets In Increasing Community Economy, International Journal of Law Recontruction, Volume 3, Issue II, September 2019, Page.114-122

8 Andri Winjaya Laksana, Sisca Dyah Octaviani, Implementation Of Law Enforcement Against Crime With Small Motive Patterned Restorative Justice In Police Sector Gayamsari of 


\section{RESULT AND DISCUSSION}

\section{Definition of Mediation and Mediator}

Mediation as an alternative dispute resolution mechanism outside the court has long been used in various business cases, the environment, labor, land, housing, consumer disputes, and so on, which are the community's demands for resolving disputes that are fast effective and efficient. ${ }^{9}$

'Mediasi' is a vocabulary or term derived from English vocabulary, namely mediation. Indonesian writers and scholars prefer to convert it into Indonesian into "mediation" as do other terms, namely negotiation to "negosiasl", arbitration to "arbitrase", and litigation to "litigasl". Lay people who often misidentified or equated between mediation and "meditasi," which originate from English vocabulary, which means meditating. Certainly, the two are very different because mediation is related to how to resolve disputes or social and legal nuances, while meditation is related to the search for inner peace or spiritual nuances.

From the perspective of the history of law at first there was no distinction between criminal law and civil law, so that every case would allow mediation. Then this dimension develops and is abandoned where it is distinguished between criminal law and civil law. However, the latest development of the community is that the practice of criminal cases is also resolved through the mechanism of deliberation or peace through the implementation of penal mediation. This aspect exists in the community as the application of the value of local wisdom and in the penal system in order to achieve restorative justice as a process of legal reform in the context of national law development. ${ }^{10}$

In the literature found many definitions of mediation. ${ }^{11}$ Mediation is a process of resolving disputes between two or more parties through negotiations or by means of consensus with the help of neutral parties who do not have the authority to decide. The neutral party is the mediator with the task of providing procedural and substance assistance. Mediation is a problem-solving negotiation process, in which the parties do not cooperate with the parties to the dispute to seek mutual agreement. The outsider is called the mediator, who is not authorized to settle disputes, but only helps the parties to solve the problems authorized by him. ${ }^{12}$

Semarang City, International Journal of Law Reconstruction, Volume III, Issue 1, March 2019, Page.20-34

9 Bambang Sutiyono, Penyelesaian Sengketa Bisnis, Solusi dan Antisipasi Bagi Peminat Bisnis dalam menghadapi Sengketa Kini dan Mendatang, Citra Media, Yogyakarta, 2008, Page.53

10 Yusriando, Implementasi Mediasi Penal Sebagai Perwujudan Nilai-Nilai Pancasila Guna Mendukung Supremasi Hukum Dalam Rangka Pembangunan Nasional, Jurnal Pembaharuan Hukum, Volume II No. 1 Januari - April 2015, Page.23-45

11 Gunawan Wijaya, Alternatif Penyelesaian Sengketa, Rajagrafindo Persada, Jakarta, 2001, Page.90-92

12 Khotibul umam, Penyelesaian Sengketa Di Luar Pengadilan, Pustaka Yustisia Publisher, Yogyakarta, 2010, Page.10 
The definition of mediation contained in PERMA No. 1 of 2016 is not much different from the definition of experts. However, in PERMA No.1 of 2016, mediation emphasizes that what is important in mediation is the mediator. The mediator must be able to find alternatives to settle the dispute. If the parties no longer find a solution to resolve the dispute, the mediator must be able to provide solutions to the parties. The solutions must be a mutual agreement from the parties to the dispute. Here is clearly seen the important role of mediators.

Mediation is a way of resolving disputes outside the court through negotiations involving a neutral (non-intervention) impartial party to the parties to the dispute being accepted by the parties to the dispute. The third party in the mediation is called a "mediator" or "the middle party", whose job is only to help the parties to the dispute in solving the problem and do not have the authority to make decisions. The mediator here only acts as a facilitator.

With mediation, it is hoped that a meeting point can be reached to resolve the problem or dispute faced by the parties, which will then be set forth as a collective agreement. Decision making is not in the hands of the mediator, but in the hands of the parties to the dispute. Mediation is basically a negotiation involving third parties who have expertise regarding effective mediation procedures, can help in conflict situations to coordinate their activities so that it is more effective in the bargaining process if there is no negotiation, there is no mediation. ${ }^{13}$

From some formulations regarding the mediation limits stated by the experts above, it can be concluded that mediation is a way of resolving disputes outside the court through an agreement to be negotiated by the parties to the dispute assisted by a neutral third party and not in favor of anyone.

The third-party is called a mediator. In this mediation, the mediator does not have the right to decide on the dispute. The mediator only helps the parties to the dispute by providing solutions that can open the minds of the parties in resolving the dispute. The solutions are negotiated by the parties to reach a mutual agreement without coercion from any party. In other words, the mediator is the mediator in a dispute.

In the Supreme Court Regulation (Perma) No. 1 of 2016 states that the mediator is a neutral party that helps the parties in the negotiation process to look for various possible dispute resolution without using a way to decide or force a settlement.

The mediator referred to in this Perma is the mediator who carries out his duties at the court. Mediators in charge of the court may come from judges of the court or from mediators outside the court. Mediator Judges are judges who carry out mediation duties after an appointment from the mediator board chairman in mediating the parties acting neutral and not taking sides with one party because taking sides of the mediator to one party will threaten the failure of mediation. The 
mediator seeks to find possible alternatives for the resolution of the parties' dispute. The mediator is also required to have some skills that can help him look for a number of possible dispute resolution.

\section{The Role and Function of the Mediator in Dispute Resolution}

The law that applies to the community is always experiencing developments following development of life so that makes the law very diverse kinds. Then the law can be studied from various specific aspects. $^{14}$ In disputes, differences of opinion and prolonged debate usually fail in the process of reaching an agreement. Circumstances like this usually end with the termination of communication lines, so that each party seeks a solution without thinking about the interests of the other party. To create an effective dispute resolution process, the requirement that must be met is that both parties must both pay attention to or uphold the right to hear. With these requirements, the dialogue process and the search for common ground, which will be the process of resolving disputes, can only proceed. The dispute resolution process requires the parties to develop a resolution so that it can be accepted together. Implementation of peace in two ways, namely outside the court hearing or through a court hearing. Outside court hearings, dispute resolution can be carried out by parties at peace either with an intermediary or by the parties' agreement. There is also what is meant by the implementation of peace described above is concerning the place and time of the implementation of the peace agreement entered into by the parties which can be classified to:

a. Peace through a court hearing

Peace through a court hearing is different from how it is outside the court hearing, peace through a court hearing is held when the case is processed before the court hearing (the lawsuit is in progress). In the provisions of the law, it is determined that before the case is processed (it can also be processed before the existence of permanent legal force), the judge must recommend that the parties to the dispute be at peace. In this case, the judge's role is undoubtedly crucial. If the judge succeeds in reconciling the disputing parties, a peace deed is made, and both parties to the dispute are sentenced to obey the contents of the peace deed.

b. Peace outside the court

In disputes, there are always two or more parties to a dispute, in disputes, the disputing parties can resolve themselves. In this case, the parties to the dispute ask for help from the relatives of community leaders / traditional leaders or other parties to find a peaceful settlement of the dispute outside the Court. However, it does not cover for the emergence of the same dispute in the future, as in the case of inheritance disputes, initially agreed that the

14 Taufiqurrohman Abildanwa, Mediasi Penal Sebagai Upaya Dalam Rangka Pembaharuan Hukum Pidana Di Indonesia Berbasis Nilai-Nilai Keseimbangan, Jurnal Pembaharuan Hukum, Volume III No. 1 Januari - April 2016, Page.138-148 
inheritance is not divided first but with the statement that the heirs are in full control as if it is private property, eliminating the inheritance rights of other heirs. Whereas initially, the agreement did not divide the past inheritance to be managed together and enjoyed together, but in reality, it is not. To avoid the recurrence of the same problem in the future, the peace agreement is often implemented in writing, made with a peace certificate.

The settlement of disputes is the choice of the Court's lane and the lane outside the Court. However, the choice of resolving disputes outside the Court is more inclined to the community to choose the resolution of it because of factors that are more towards the goodness and kinship. The choice of dispute resolution process outside the Court, namely Alternative Dispute Resolution (ADR), arbitration, and deliberation, aims at peace following the wishes of the parties to the dispute. Alternative Dispute Resolution and arbitration are more about business law issues, which are closed and do not take a long time, such as legal cases settlement through the Court. In the realm of civil law outside of business law, which have entered the Court's path, there is still a peace process for the beginning, where appointed judges to carry out the peace if peace can be realized with both parties' desire is no element of coercion. There will be a judge's decision regarding peace. ${ }^{15}$

Alternative Dispute Resolution and arbitration are more about business law issues. However, ADR does not cover the existence of a dispute resolution system that can also be applied to civil cases other than civil cases in the field of business law because the goal is the same, which leads to peace and which is closed and does not take a long time such as the resolution of legal cases through the Court, namely negotiation and mediation. Negotiation is a two-way communication that is designed to reach an agreement when both parties have the same or different interests. Negotiations are a means for disputing parties to discuss them.

\section{Civil Disputes Through Local Wisdom Value-Based Mediation in Progressive Legal Perspective}

The law was created for humans. Thus the law always influences and influences with various components contained around humans. The law does not move in a vacuum that is free of value, but rather it is within a certain social order and living humans. Law is understood as the building of rules and the building of ideas, culture, and ideals. So it can be understood that the law is not only seen as rules and procedures that all mean free of value. The law is seen functionally related to efforts to maintain social life continuity, such as maintaining peace, resolving disputes, and eliminating deviations. In short, the law maintains order and controls. Law is like water will find its own surface, which not only

15 Suyud Margono, ADR (Alternative Dispute Resolution) dan Arbitrase, Ghalia Indonesia, Jakarta, 2000, Page.48 
differs from one community to another, but it also changes in these societies. ${ }^{16}$

Dispute resolution using a local value model and approach is one alternative to the dispute resolution model because local values can pay attention to any issues that are confronted with it specifically and holistically. ${ }^{17}$ This is what is meant by Carl Von Savigny with the famous Volkgeist theory, namely the law is sourced from the soul of the people's national identity. Furthermore, Eugen Ehrlich conveys "living law" which is the real law of life in society.

It appears from what is mentioned above, the law is not just a black and white formula as in various laws and regulations, but the law should be seen as a symptom that can be observed in public life which this means the law is much influenced by non-legal factors such as values, attitudes, and way of life of people commonly referred to as legal culture. This legal culture makes the difference between the operation of law in one community and another.

Daniel S. Lev tries to use the concept of legal culture to analyze changes in the Indonesian legal system that divides the legal culture into procedural legal values and substantial legal values. The value of procedural law questions about how to regulate the order of society and how to resolve disputes, thus it will help determine how the place is given to legal, political, and other institutions throughout the history of the nation and society concerned. While substantial values consist of the basic assumptions regarding the distribution and use of resources in the community about what is considered good, right, fair, or not in the community concerned. ${ }^{18}$

Law enforcement can be observed in reality, which involves its cultural dimension, namely legal culture, which shows how the perception of the community and law enforcement officials of the law and how the law must be enforced. Legal culture is any form of human cultural behavior that influences or is related to legal issues. Satjipto Raharjo analyzed how the actual legal culture prevails in Indonesian society in general. ${ }^{19}$ The basis of his opinion stems from the assumption that in the operation of the law, the thing that cannot be ignored is the role of the people/community members who are the target of legal arrangements and is determined by the attitudes, views, and values lived by members of the community. Satjipto Rahardjo, sees the culture of law as the basis for the implementation or not of positive law in society because the implementation of positive law is largely determined by the attitudes, views, and values they live.

16 Daniel S.Lev, Lembaga Peradilan dan Budaya Hukum Di Indonesia, in Peters-Koesriani Siswosoebroto, Law and Social Development of the Nuku Legal Sociology Text Book II, Pustaka Sinar Harapan, Jakarta, 1988. Page. 258

17 Moh. Koesnoe, Hukum adat sebagai Suatu Model Hukum. PArt I (Historical), Mandar Maju, Bandung, 1992, Page. 10-11

18 Daniel S. Lev, Op.Cit, page. 247

19 Satjipto Raharjo, Hukum Dan Perubahan Sosial Suatu Tinjauan Teoritis dan Pengalamanpengalaman di Indonesia, Alumni, Bandung, 1979, page.10 
namely: ${ }^{20}$

The concept of legal culture from Lawrence M. Friedman,

a. Legal culture refers to parts of the culture in general (habits, opinions, ways of acting and thinking), which in certain ways can move social forces closer to or away from the law.

b. A legal culture determines when, why, and how people treat the law. Legal institutions or legal processes and why they use other institutions or do not use them at all. It is cultural factors that change the structure and rules of static law into living law.

c. Legal culture is attitudes, values, and opinions of the community in dealing with the law and legal system, legal culture is the source of law.

d. Legal culture is a network of values and attitudes related to law, which determines when, why, and how people obey or reject the law, determine what legal structure is used, and the reasons and what legal rules are chosen to be applied and set aside and what the reason.

e. Legal culture is the ideas, attitudes, hopes, and opinions about law maintained by citizens.

The concept of legal culture can draw attention to values related to law and due process, but which can be distinguished analytically from them and are considered to be independent. These values are the cultural basis of the legal system. They are very helpful in determining the system of giving place to legal, political, religious, and other institutions at all times in the history of a society. Legal culture consists of fundamental assumptions regarding the distribution and use of community resources, social good and bad, and so on.

Legal culture can be used to understand people's behavior both at the Regulators, Peniculators, and role holders. The human actor does not merely react to others' actions, but he interprets and defines the actions of others. Actors' responses, directly or indirectly, are always based on evaluating the meaning. Therefore, human interaction is bridged by the use of interpretive symbols or by finding meaning in others' actions. A complete analysis of human behavior will be able to capture the meaning of symbols in interactions. ${ }^{21}$

By referring to the opinion of Satjipto Rahardjo and Lawrence Friedman, the connection with the settlement of civil disputes between the parties through mediation is a way to overcome the complexity of the problems faced. The Indonesian legal culture, which emphasizes solving problems based on the spirit of deliberation and consensus as

20 Teddy Asmara, Disertation entitled Budaya Ekonomi Hukum Hakim; Kajian Antropologi tentang Rasionalitas Ekonomik pada Penggunaan Kebebasan Hakim dalam Penanganan Perkara Pidana di Pengadilan Negeri Kotamaju, Undip Law Doctoral Program, Semarang, 2010, page. 51

21 Bagong Suyanto \& Sutinah, Metode Penelitian Sosial Berbagai Alternatif Pendekatan, Kencana, Jakarta, 2005, page.137 
living values in society, is then crystallized in Pancasila's principles as things that should be the focus of solving problems that arise.

Mediation through deliberation is a way to resolve disputes in an appropriate, effective manner and open wider access to the parties to obtain a satisfactory and just settlement. Peace is the best way to resolve disputes between litigants. With peace, litigants can explore a resolution that is mutually beneficial to one another. In peace, what is emphasized is not merely the legal aspect, but how both parties can still benefit as much as possible from the choices they agree on. Here also shows that with peace, the settlement would prioritize humanity and the desire to help and share with each other. No party loses or wins. There are only those who win together.

In Satjipto Rahardjo's view, that law is only one of the institutions in society that helps create order. Law order is a configuration of institutions such as law and tradition. ${ }^{22}$ What is meant by tradition is the sedimentation of living habits, which are indeed owned and trusted by Indonesian society. As the Indonesian legal community's culture, it is said to be an unwritten legal culture, so that the Indonesian people's overall legal culture is the legal culture of "living law"

The existence of local values as a living law is felt to be effective by the community, especially the environment of indigenous peoples who still maintain the value of their local wisdom, it is not impossible in civil disputes they do not want to be compartmentalized in the bulkhead to win because of the decision of the judge. There are winners and parties that were defeated, so it moved away from the value of substantive justice.

For example, the philosophy that lives "ono rembug yo di rembug" when a problem occurs in Javanese terms, implies the spirit of deliberation. The application of the concept of deliberation in a mediation program as a basic principle that animates civilized communities, through deliberation, any issues involving personal interests, public interests, and the community's interests will be able to get out of disputes between them.

Furthermore, the principle of deliberation aims to involve or invite all parties to participate in social life, so that loyalty and obedience to what is agreed upon by the community will also be maintained together because the agreement is thought and opinion in the nuances of kinship and mutual glory. This means that if there are parties who violate the same as breaking up brotherhood and kinship and not respecting others. ${ }^{23}$

Quoting Satjipto Rahardjo's view, progressive law does not accept the law as an absolute and final institution but is largely determined by its ability to serve humans. In the context of this thinking, the law is

22 Satjipto Rahadjo, IImu Hukum, Citra Aditya Bakti, Bandung, 1996, page. 23

23 Syaifuddin Iskandar \& Lahmudin Zuhri, Posisi Nilai Lokal Dalam Peraturan Daerah, Journal of Unsa Progress, Samawa Sumbawa Besar University, Vol 18, 2015, No. 23 
always in the process of continuing to be. ${ }^{24}$ Indonesian society actually has a value that lives in everyday life, namely deliberation. In the reality of dispute resolution, the community seems to have lost the appreciation and practice of the value of deliberation. The community tends to thrive on resolving disputes with violence and the culture of suing. The parties in dispute in court tend to be unwilling to re-discuss to reach a win-win solution. It should be emphasized here that civil disputes are born because each party to the dispute insists that the disputed object is his / her right, so that the culture of deliberation, which has noble values in dispute resolution, begins to be abandoned and shifts to modern dispute resolution using court equipment. ${ }^{25}$

Thus, in a civil dispute through mediation encouraged by a sense of deliberation for the achievement of shared justice, it wants to restore it in a harmonious and peaceful state. That the law is for humans, not humans for the law, whose purpose is to bring people to prosperity and happiness. So that mediation with the value of local wisdom must be the basis of resolution in civil disputes by considering:

a. Referring to the win-win solution principle, what is meant by the disputing parties feel that no one is defeated.

b. Achieve the inner glory and inner peace of the parties

c. Reinforcement of family values and sense of belonging to the disputing parties.

\section{CONCLUSION}

The purpose of the research is intended to bring people to prosperity, happiness and harmony, so that there is mediation with the value of local wisdom must be the basis of resolution in civil disputesIn civil disputes through mediation, the existence of local values with an emphasis on the principle of deliberation and kinship as a living law that is felt to be effective and fair, especially the environment of indigenous peoples who still maintain the value of their local wisdom, in disputes the parties do not wish to enter into space seeking victory because of the existence the decision of the judge, so there is a party that wins and the party that is defeated because it actually moves away from the value of substantial justice. That the law is for humans, not humans for the law, whose purpose is to bring people to prosperity, happiness, and harmony. So that there is mediation with the value of local wisdom must be the basis of resolution in civil disputes with due regard to Referring to the win-win solution principle, what is meant by the disputing parties feel that no one is defeated, Achieve the inner glory and inner peace of the parties, Reinforcement of family values and sense of belonging to the disputing parties.

24 Satjipto Rahadjo, Hukum Progresif : Aksi, Bukan Teks dalam Bukunya Memahami Hukum dari Konstruksi sampai Implementasi, Rajawali Press, Jakarta, 2009, page.3

25 Rahadi Wasi Bintoro, Kajian Ontologis Lembaga Mediasi di Pengadilan, Yuridika: Volume 31 No 1, Januari 2016, page.121-142 


\section{BIBLIOGRAPHY}

\section{Books :}

Bambang Sutiyono, 2008, Penyelesaian Sengketa Bisnis, Solusi dan Antisipasi Bagi Peminat Bisnis dalam menghadapi Sengketa Kini dan Mendatang, Citra Media, Yogyakarta;

Daniel S.Lev, 1988, Lembaga Peradilan dan Budaya Hukum Di Indonesia, in Peters-Koesriani Siswosoebroto, Law and Social Development of the Nuku Legal Sociology Text Book II, Pustaka Sinar Harapan, Jakarta;

Gunawan Wijaya, 2001, Alternatif Penyelesaian Sengketa, Rajagrafindo Persada, Jakarta;

Khotibul Umam, 2010, Penyelesaian Sengketa Di Luar Pengadilan, Pustaka Yustisia Publisher, Yogyakarta;

Mahkamah Agung, 2004, Mediation and Peace, MA-RI, Jakarta;

Mochtar Kusumaatmadja, 2012, Mochtar Kusumaatmadja dan Teori Hukum Pembangunan, Epistama Institute dan Huma, Jakarta;

Moh. Koesnoe, 1992, Hukum adat sebagai Suatu Model Hukum. PArt I (Historical), Mandar Maju, Bandung;

Satjipto Raharjo, 1979, Hukum Dan Perubahan Sosial Suatu Tinjauan Teoritis dan Pengalaman-pengnlaman di Indonesia, Alumni, Bandung;

, 1996, IImu Hukum, Citra Aditya Bakti, Bandung;

2009, Hukum Progresif : Aksi, Bukan Teks dalam Bukunya Memahami Hukum dari Konstruksi sampai Implementasi, Rajawali Press, Jakarta;

Sudikno Mertokusumo, 1988, Mengenal Hukum (suatu Pengantar), Liberty, Yogyakarta;

Suyud Margono, 2000, ADR (Alternative Dispute Resolution) dan Arbitrase, Ghalia Indonesia, Jakarta;

\section{Journal :}

Ahmad Rofiq, Hari Sutra Disemadi, and Nyoman Serikat Putra Jaya, Criminal Objectives Integrality in the Indonesian Criminal Justice System, Al-Risalah 19, no. 2 (December 16, 2019);

Andi Aina Ilmih, Kami Hartono, Ida Musofiana, Legal Aspects Of The Use Of Digital Technology Through Sharia Online Transactions In Traditional Markets In Increasing Community Economy, International Journal of Law Recontruction, Volume 3, Issue II, September 2019;

Andri Winjaya Laksana, Sisca Dyah Octaviani, Implementation Of Law Enforcement Against Crime With Small Motive Patterned Restorative Justice In Police Sector Gayamsari of Semarang City, 
International Journal of Law Reconstruction, Volume III, Issue 1, March 2019;

Dini Amalia Fitri, Pancasila As A Legal Science Paradigm, International Journal of Law Reconstruction, Volume 3, Issue 1I, September 2019;

Netty Herawati, Implikasi Mediasi Dalam Perkara Perdata di Pengadilan Negeri Terhadap Asas Peradilan Sederhana, Cepat, dan Biaya Ringan, Journal Perspective, Volume XVI No. 4 September 2011;

Rahadi Wasi Bintoro, Kajian Ontologis Lembaga Mediasi di Pengadilan, Yuridika, Volume 31 No 1, Januari 2016;

Syaifuddin Iskandar \& Lahmudin Zuhri, Posisi Nilai Lokal Dalam Peraturan Daerah, Journal of Unsa Progress, Samawa Sumbawa Besar University, Vol 18, 2015;

Taufiqurrohman Abildanwa, Mediasi Penal Sebagai Upaya Dalam Rangka Pembaharuan Hukum Pidana Di Indonesia Berbasis Nilai-Nilai Keseimbangan, Jurnal Pembaharuan Hukum, Volume III No. 1 Januari - April 2016;

Yusriando, Implementasi Mediasi Penal Sebagai Perwujudan Nilai-Nilai Pancasila Guna Mendukung Supremasi Hukum Dalam Rangka Pembangunan Nasional, Jurnal Pembaharuan Hukum, Volume II No. 1 Januari April 2015; 